stable economic growth from non-renewable resources, preservation and conservation of Yukon's wilderness, and greater understanding of aboriginal knowledge and resource management practices. Several suggested actions that could be implemented to achieve these objectives are outlined.

The discussion paper is now undergoing a process of intensive public and government review, including briefing sessions with interest groups, federal and territorial government departments, and municipalities outside the capital city of Whitehorse; public seminars and workshops on particular subject-areas; and written responses to the discussion paper. Additional promotion in the form of posters, lapel pins, and a large and colourful mobile display, all specifically developed for the conservation strategy, have helped to advertise and encourage public awareness of the strategy and its fundamental principles.

Following the public review, a draft conservation strategy, incorporating comments and input from all sectors, will be prepared. The final Yukon Conservation Strategy, which will provide a broad framework for natural resource management that combines environmental protection and sustainable resource development, is scheduled for completion in due course.

\section{Implementation of Strategy}

When once the Strategy is in place, the ongoing implementation will include demonstration projects that provide concrete examples of the integration of conservation and development activities. Several projects already under way in the Yukon reflect the importance of this relationship. As one example, the Yukon's largest mining company is currently working with the Department of Renewable Resources to reroute the seasonal migration path of a herd of rare Fannin sheep around an ore deposit that is to be mined, and thus avoid potential loss of the sheep population. The project also provides an opportunity to develop a wildlife-viewing area where local residents and tourists can observe the sheep.

The implementation of the Yukon Conservation Strategy will also be assisted by other developments linked to the Territory's constitutional advancement, such as the transfer of additional resource responsibilities to the $\mathrm{Yu}$ kon Government, and a land-claims settlement for the Yukon's aboriginal people. The Territorial Government is pursuing the transfer to its control of natural resource responsibilities currently in federal hands. such as forestry. land, and water; these transfers will facilitate the integrated management of the Yukon's resources. The framework agreement for the land-claims settlement, reached in 1988. contains provisions for the establishment of a process to review and assess the effects of development on the environment, economy, and society, and to provide for measures to mitigate the negative impacts of development activities. Another requirement of the settlement will be the creation of community-based renewable resource councils with aboriginal and non-native membership, to give local residents a voice in fish and wildlife management.

Throughout its implementation, the Yukon Conservation Strategy will function as a plan to guide efforts to strengthen and reinforce economic activities that are compatible with the environment, to protect the environment on which these activities depend, and to maintain the range of life-style options that Yukoners now enjoyincluding the traditional pursuit of subsistence harvesting of renewable resources. The Conservation Strategy will also provide a means of evaluating the effectiveness of demonstration projects and other implementation tools in the achievement of sustainable, environmentally sound economic development in this northern Canadian Territory.

W.J. KLASSEN, Deputy Minister
Renewable Resources
Government of the Yukon
Whitehorse
Yukon, Canada.

\title{
National Institute for Urban Wildlife
}

Founded in 1973, the National Institute for Urban Wildlife is a private, non-profit scientific and educational organization. It is dedicated to research, planning, management, and conservation education, programmes and activities for the benefit of wildlife and people in urban, suburban, and urbanizing, areas. So far as we are aware, it is the only organization of its kind in the United States or elsewhere with a primary focus on fish, other wildlife, and related resources, in the metropolitan environment. Funded through private contributions, grants and contracts, and individual and corporate memberships, it strives to fill some of the glaring gaps in information and methodologies which are needed for the management and enjoyment of wildlife and wildlife habitats in urban areas.

The Institute accomplishes its mission by: (1) conducting research on the relationships between Mankind and wildlife under urban and urbanizing conditions; (2) discovering and disseminating practical procedures for maintaining and enhancing wildlife populations, and controlling certain wildlife species in urban areas; (3) building an appreciation for, and an understanding of, wildlife and wildlife needs; (4) establishing a positive conservation ethic through education programmes directed at the community and neighbourhood levels; and (5) illustrating how all segments of our population have a vested interest in wildlife and the environment which we share mutually.
Most of the work of the Institute results in some form of publication - scientific, technical, semi-technical, or popular-for various audiences. Examples include Leedy et al. (1978), Leedy (1979), Leedy et al. (1981), Adams \& Dove (1984), Leedy \& Adams (1984), Adams \& Leedy (1987). and Adams \& Dove (1989). A quarterly newsletter, Urban Wildlife News, is also published, along with an accompanying supplement, Urban Wildlife Manager's Notebook.

Recently, an Urban Wildlife Sanctuary Program was initiated. The purpose of this programme is to establish and certify a network of urban wildlife sanctuaries on public and privately-owned lands across the nation, in order to: (1) enhance urban wildlife habitat, (2) promote an understanding of, and appreciation for, urban wildlife and its habitat needs, and (3) recognize private and public landowners who dedicate their properties to wildlife. The programme is broad and applies to properties of individuals. neighbourhood associations, community organizations, cities and towns, corporations, and developers.

Since 1975, the Institute has organized annual informal open exchange meetings in conjunction with the North American Wildlife and Natural Resources Conference. The meetings are designed to provide an opportunity for those who are interested in urban wildlife to get together and discuss programmes, policies, and research and management activities. 


\section{REFERENCES}

Adams, L.W. \& Dove, L.E. (1984). Urban Wetlands for Stormwater Control and Wildlife Enhancement. National Institute for Urban Wildlife, Columbia, Maryland, USA: 15 pp., illustr.

ADams, L.W. \& Dove, L.E. (1989). Wildlife Reserves and Corridors in the Urban Environment: A Guide to Ecological Landscape Planning and Resource Conservation. National Institute for Urban Wildlife, Columbia, Maryland, USA: vi + 91 pp.. illustr.

Adams, L.W. \& Leedy, D.L. (Eds) (1987). Integrating Man and Nature in the Metropolitan Environinent. National Institute for Urban Wildlife, Columbia, Maryland, USA: viii +249 pp., illustr.

LeEdy, D.L. (1979). An Annotated Bibliography on Planning and Management for Urban-Suburban Wildlife. FWS/OBS79/25, US Fish and Wildlife Service, Washington, DC. USA: $256 \mathrm{pp}$.
LEEDY, D.L. \& ADAMS, L.W. (1984). A Guide to Urban Wildlifo Management. National Institute for Urban Wildlife, Columbia, Maryland, USA: ii + 42 pp., illustr.

Leedy, D.L., Maestro, R.M. \& Franklin, T.M. (1978). Planning for Wildlife in Cities and Suburbs. FWS/OBS-77/66. US Fish and Wildlife Service, Washington, DC, USA: vii + 64 pp.. illustr.

Leedy, D.L., Franklin, T.M. \& Maestro, R.M. (1981). Planning for Urban Fishing and Waterfront Recreation. FWS/OBS80/35, US Fish and Wildlife Service, Washington, DC. USA: viii +108 pp., illustr.

LOWELl W. ADAMS, Vice-President for Research National Institute for Urban Wildlife 10921 Trotting Ridge Way

Columbia

Maryland 21044

USA.

\section{International Association for Impact Assessment}

The International Association for Impact Assessment (IAIA) is an organization of research workers and other professionals, as well practitioners and users of impact assessment. It was formed in 1981 and has since grown to comprise a membership of 575 people in 45 countries. Each year the Association convenes a conference or smaller meeting to share the experiences of its members concerning the impact of plans, projects, programmes, and other developments, occurring throughout the world. In some instances IAIA Chapters will hold meetings, and several regional meetings have occurred. Regional Chapters exist, or are being organized, in Australia, New Zealand, the Caribbean, Western Europe, and North America.

The main goal of IAIA is to advance the state of the art of impact assessment and to foster its application to impact situations and conditions at scales ranging from local all the way to global ${ }^{*}$. Forms of impact assessment include: technology assessment, environmental impact assessment, social impact assessment, and risk assessment. Equally, we encourage the development of international and local capability to anticipate, plan, and manage, the conse-

\footnotetext{
* and in due course, doubtless, Universal.-Ed.
}

quences of impacts, so as to enhance the quality of life for all.

IAIA provides a non-political forum to exchange ideas and experiences. It aims to stimulate innovation in dealing with the consequences of development. Opportunities for IAIA participation include research networks around specialized assessment topics of interest to members-such as robotics, social forecasting, and international impacts.

Members of the IAIA receive the Impact Assessment Bulletin, a quarterly of short articles and reviews, and a newsletter on current events and IAIA activities. The 1990 IAIA Annual Conference is scheduled for Beijing, China, and will concentrate on the theme: Development and Environment. Dues are: Individual Members, $\$ 30$ US; Joint Members, $\$ 40$ US; Student or Retired, \$15 US; and Institution, $\$ 60$ US. Further details can be obtained from the undersigned:

\section{David HaRdy, Secretary}

The International Association for Impact Assessment c/o Industrial and Systems Engineering Georgia Institute of Technology

Atlanta

Georgia 30332, USA.

\section{Aims and Activities of Sol 3}

Sol 3 was founded in 1986 with the specific aim of bringing together mature individuals from all over the world with a common interest, so that they might study together and exchange ideas. Although originally conceived as a study-group for those interested in mathematics and the physical sciences, our group has more recently, and at the request of members, become concerned with ecological and humanitarian issues.

We are not an organization as such, but rather an informal affiliation of aware individuals. Members are welcome to use our facilities at any time, to exchange ideas, or to follow some formal course of study or research. The group is funded by donations from members, but no member is under any obligation to contribute to any specific project.

In February 1989, our First International Assembly on Deforestation was held in our village in Valais, Switzerland, with representatives from groups based in Geneva, but working on projects as far apart as Brazil, Haiti, and various parts of Africa. April 1989 saw the Second International Assembly on Deforestation take place in Geneva, with almost 50 organizations represented, and from almost all parts of the world.

Since then, we have sponsored a representative to the Enquete-Kommission in Bonn, and produced a report, which is currently being circulated, on the annual destruction wreaked by burning and other means in the Brazilian Amazon. One of our members is attending the Planetterre conference in Paris.

During 19-20 June 1989 we held a Round Table, as a follow-up to the April Assembly, at which a number of experts from the fields of law, economics, and sociology, met and discussed with environmentalists the causes of environmental destruction, and suggested possible courses of action. But why Sol 3 ? It is very simple-not an acronym - but count outwards from the Sun and the 3 represents a planet of special importance to us all.

CARL M. Haigh

Sol 3

3961 Vissoie

Valais

Switzerland. 